\title{
Alföldy Zoltán professzor 25 éven át (1950-1974) \\ a Mikrobiológiai Intézet élén
}

\author{
Nász István dr. \\ Semmelweis Egyetem, Általános Orvostudományi Kar, Orvosi Mikrobiológiai Intézet, Budapest
}

\section{Az első évek}

Alföldy professzor nagyon nehéz körülmények között vette át az intézet vezetését 1950 őszén, ugyanis 1950 tavaszán egy súlyos, tragikus szérumszerencsétlenség történt az előzőleg a Faragó Ferenc professzor által mintegy két éven keresztül vezetett, 1948-ban létrehozott intézetben. Faragó professzor sok értékes tudományos munkája mellett többek között a szamárköhögés megelőzésével, gyógyításával foglalkozott és kidolgozta a megelőzést és gyógyítást szolgáló emberi hiperimmunszérum elóállítási technikáját. A szérumot az intézetben tisztították, szürték, ampullázták és megrendelésre küldték a megfelelő gyermekgyógyászati intézményekbe. Az intézetben egyesek tetanuszvizsgálatokkal is foglalkoztak, és 1950 májusában egy széria hiperimmunsavóba máig nem tisztázott módon - tetanusztoxin került és úgy ampullázták és küldték szét. Ennek következményeként tíz csecsemő tetanuszmérgezés következtében életét vesztette. Az ügyben politikai jellegü peres eljárás indult, Faragó professzort és négy közvetlen munkatársát letartóztatták, elítélték és bebörtönözték, Faragó professzor pedig 1950. június 10-én, a vizsgálati fogságban meghalt. A bebörtönzött munkatársakat a perújrafelvétel alapján 1953-ban rehabilitálták.

Intézetünk vezetésével átmeneti időszakra a Kórélettani Intézet igazgatóját, Sós József professzort bízták meg, az ő feladata volt a pártmegbízottal együtt az intézeti helyzet rendezése. Ennek során többen önként távoztak az intézetből, többeket pedig áthelyeztek az Országos Közegészségügyi Intézetbe (OKI). Az oktatómunkát és a tanév végi vizsgáztatást a megzavart „maradék" személyzettel kellett megszervezni. Szigorlatoztatásra képes oktató nem maradt az intézetben, ezért az intézetből még az események előtt a II. Gyermekklinikára távozott Novák Ernő föorvost kérték fel.

Ilyen körülmények között bízták meg Alföldy Zoltánt, az OKI Bakteriológiai Osztályának vezetőjét az intézet igazgatásával, aki saját elmondása szerint nem vágyott

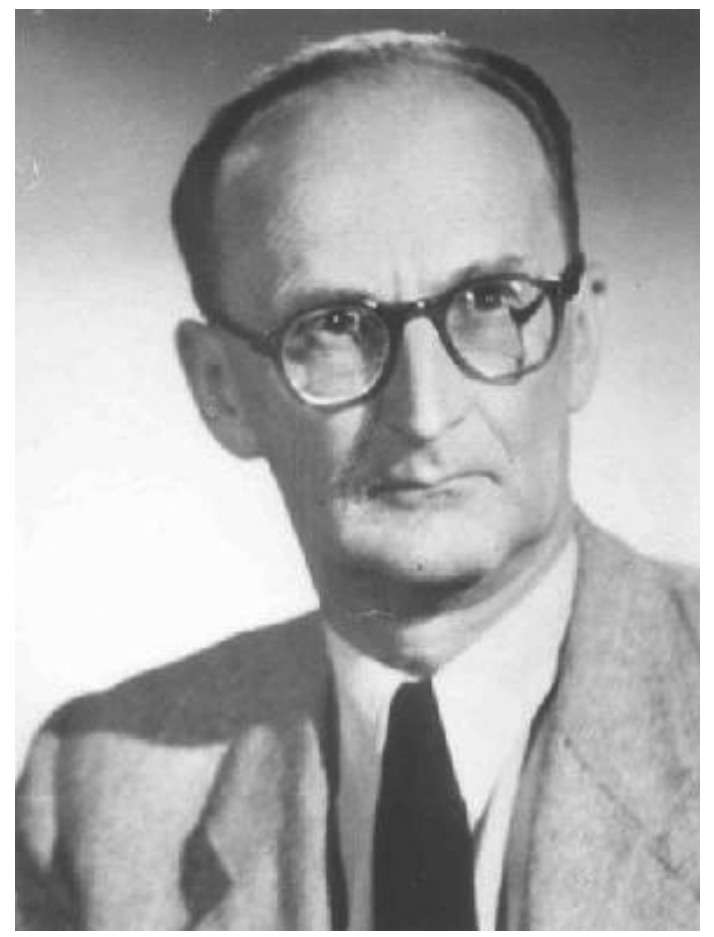

1. ábra | Alföldy Zoltán professzor (1904-1992)

erre a posztra, „Csak rám esett a választás” - mondta (1. ábra). A pesti egyetemet nem ismerte, és nagy erófeszítésre volt szüksége, hogy el tudja látni ezt a számára teljesen új és szokatlan feladatot. Az intézetben csak még egyetemet sem végzett demonstrátorok és egészen frissen végzett fiatal orvosok voltak. Ezért több szigorló orvost - köztük engem is - kineveztek egyetemi gyakornoknak. Nem volt egyetemi tankönyv a hallgatóság számára, amit úgy oldottunk meg Alföldy professzor vezetésével, hogy az előadások témaköreinek megfelelően, azok előrehaladásával párhuzamosan, elméleti jegyzetfüzeteket írtunk folyamatosan és bocsátottunk a hallgatóság rendelkezésére. 


\section{Hogyan lett orvos és mikrobiológus?}

„Nem szégyellem bevallani, hogy soha életemben nem akartam orvos lenni!" - mondta a Jahn Ferenc Kollégium által, az egyetemi professzorokkal rendezett találkozón (1978), ahol részletesen elmesélte élettörténetét, ami a "Gyógyító tudósok" címú könyvben írásban is megjelent (1982). Erdész szeretett volna lenni, de édesapja, aki bányamérnök volt és végigszenvedte az I. világháború négy esztendejét, sokszor megsebesült és sokat volt kórházban, lassanként meggyőzte arról, hogy egy szép foglalkozás van csak, orvosnak lenni, amit ő elfogadott és így lett orvos. 1922-ben került Debrecenbe az egyetemre, Erdélyből, Nagybányáról (ma: Baia Mare, Románia), ahogy gyakran említeni szokta, de valójában egy közeli faluban született, Alsófernezélyen (ma: Ferneziu, Románia) 1904. január 27-én. Az egyetemet nehéz anyagi körülmények között végezte el, mert otthonról alig kaphatott anyagi támogatást, mivel Nagybánya - Trianon következményeként - akkor már nem tartozott Magyarországhoz. Az egyetem elvégzése után a debreceni Belklinikára került, ahol „díjtalan gyakornok” volt, fizetést csak két év múlva kapott. Kilenc évet mint belgyógyász és röntgenológus szakorvos dolgozott. Debreceni évei alatt, az 1930as évek elején szörnyüséges tapasztalatot jelentett neki az abban az időszakban kulmináló hastífuszjárvány. A klinikán volt tífuszosztály, és egy évig ő volt az osztály vezetője. Nem volt a városnak fertózókórháza. Szinte tehetetlenül álltak a betegágy mellett, egyedül a lázcsillapító Piramidont használhatták gyógyszerként, mert abban az idóben más még nem létezett, és ha bekövetkezett a bélvérzés, akkor elvérzett a beteg, és ha perforált, akkor peritonitisbe halt bele. Maguk az orvosok is állandó félelemben éltek, orvostársak, ápolók pusztultak el tífuszban, és így dolgoztak éveken keresztül. Ez volt az oka, hogy Alföldy professzor eljött a klinikáról, mert úgy látta, hogy a hastífuszkérdést nem lehet megoldani a betegágy mellett, valahogy másként kell hozzányúlni. Ezért, amikor 1938-ban Budapesten Esterházy Pál herceg anyagi segítségével az OKI-ban meghirdették a hastífusz elleni kutatási programot, oda jelentkezett és ebbe a munkába kapcsolódott be, amivel a bacilusgazda-kérdést sikerült tisztázni, ami nagy dolog volt, de még nem elég. Akkor viszont közbejött a II. világháború, ami visszavetette a kutatást, de utána is folytatták a munkát, és a bacilusgazda-kutatásban és a védőoltás kifejlesztésében értek el fontos eredményeket. 1950-ben azonban Alföldy profeszszort, mint az OKI Bakteriológiai Osztályának vezetőjét, áthelyezték a Mikrobiológiai Intézet megbízott igazgatójának és akkor a kutatómunkája is más irányba fordult, amiről a későbbiekben fogok beszámolni.

\section{Oktatómunka}

Az intézet fiatal tagsága mellé Alföldy professzor rövidesen meghívott két idősebb munkatársat, Fazekas Lászlót és Fưzi Miklóst, akik rövidesen docensi kinevezést kap-

\section{ORVOSI MIKROBIOLÓGIA}
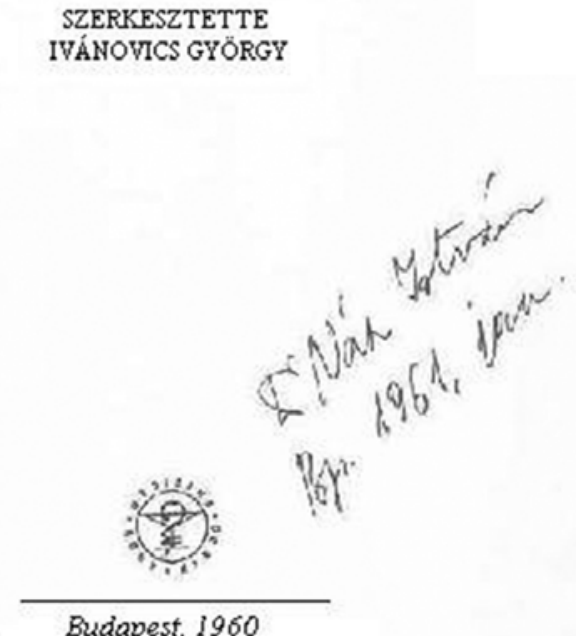

2. ábra

Az első magyar nyelvű hivatalos tankönyv az Általános Orvostudományi Kar hallgatói számára

tak, és Fazekas doktort megbízták a Gyógyszerésztudományi Karon a mikrobiológia megbízott előadói, Fúzi doktort pedig a Fogorvostudományi Karon a mikrobiológia megbízott előadói feladatok ellátásával. Hivatalos egyetemi tankönyv még sokáig nem volt. Többször is írtunk jegyzeteket az ÁOK-hallgatók számára, amit csak úgy jeleztünk, hogy „írta az Intézet munkaközössége”. Később Fazekas doktor külön jegyzetet írt a gyógyszerészhallgatók számára, három kiadásban is. Fazekas doktor 1961-ben eltávozott az intézetből, és akkor engem bíztak meg a Gyógyszerésztudományi Karon a megbízott előadói feladatok ellátásával, és 1970-ben írtam egy jegyzetet a gyógyszerészhallgatók igényeinek megfelelő tartalommal. 1970-1973 között dékánhelyettes voltam a Gyógyszerésztudományi Karon. Zoltai Nándor OKIosztályvezető mint meghívott előadó külön jegyzetet írt az orvosi szempontból fontos parazitákról. Volt ugyan az '50-es évek elején egy oroszból fordított tankönyv - Arisztovszkij: Mikrobiológia -, amely modern tankönyv volt ugyan, de nem felelt meg a hazai körülményeknek és követelményeknek, ezért nem használtuk.

Az ÁOK-hallgatók számára nívós, hivatalos egyetemitankönyv-ellátás csak akkor indult meg, amikor Alföldy Zoltán, Rauss Károly (Pécs) és Ivánovics György (Szeged) professzorok összefogtak, és 1960-ban megjelentették az „Orvosi mikrobiológia” címú egyetemi tan- 
ALFÖLDY ZOLTÁN - NÁSZ ISTVÁN

\section{I K R OB I O L Ó G I A}

\author{
GYÓGYSZERÉSZ-ÉS FOGORVOSTAN-HALLGATÓK \\ RESZERE
}

Második átdolgozont kiadás

MEDICINA KÖNYVKIADÓ - BUDAPEST 1974

3. ábra

Az első magyar nyelvű hivatalos tankönyv a Gyógyszerésztudományi Kar és a Fogorvostudományi Kar hallgatói számára

könyvet, amely összesen négy kiadást ért meg Alföldy Zoltán professzor szerkesztésében az 1973-ban megjelent utolsó kiadásig (2.ábra). Ezután folytatódott ennek példáján az olyan hivatalos tankönyvek írása, amelyeket a négy orvosegyetem Mikrobiológiai Intézeteinek vezetői és munkatársai írtak. De ezzel még mindig nem volt megoldva a két másik kar hallgatói igényei szerint írt tankönyvellátás. Ezért határoztuk el Alföldy professzorral, hogy a gyógyszerészhallgatók speciális oktatásához is külön tankönyvet írunk. 1974-ben jelent meg AlföldyNász: „Mikrobiológia” címú könyvünk, ennek második kiadására újraírt változatban 1978-ban került sor, amely már a Fogorvostudományi Kar hallgatói speciális igényére is figyelemmel volt és az ő számukra hivatalos tankönyvként szolgált (3. ábra). Ezek a könyvek más egyetemek és karok hallgatói között is keresettek voltak, mert viszonylag röviden, szinte teljes tájékoztatást adtak az orvosi és egészségügyi jellegű mikrobiológia tárgyköréből.

A hallgatóság számára a mikrobiológiai gyakorlatokat a Hőgyes Endre utcai tanterem előterében és kétoldalt, a tanterem mellett húzódó keskeny, alig egy méter széles oldalfolyosókon kialakított gyakorlati laboratóriumokban voltunk kénytelenek tartani, mert nem volt más lehetőség. Jelentős javulást jelentett azonban, hogy 1964ben az épület alagsorának utcai részében három, viszonylag modern gyakorlati termet sikerült létrehozni Alföldy és Sós professzorok hathatós kérésére. Ezekben a termekben folytak a mikrobiológiai és a kórélettani gyakorlatok felváltva, egészen a Nagyvárad téri elméleti tömbbe (NET) történt átköltözésünkig (1977-1978).

A mikrobiológiai és kórélettani előadások a Hőgyes Endre utcai tanteremben folytak. Előadási segédeszközök nem nagyon voltak, csak krétával lehetett a lényeges adatokat felírni a falba épített két nagy, felfelé és lefelé mozgatható táblára. Nagy áttörést jelentett azonban az, hogy Alföldy professzor kitalálta és bevezette az óriásábrák készítését és bemutatását - amiket mi „vitorláknak" neveztünk - a tanteremben kifüggesztve. Ezek 2-4 négyzetméter nagyságúak vagy még nagyobbak is lehettek és csak a padlóra kiterítve tudták a munkatársak elkészíteni azokat. Sok ilyen ábra és táblázat készült, szinte az egész mikrobiológiai tananyagot magába foglaló témákról. Az ábrák meg voltak számozva, elnevezve, külön lapokon katalogizálva és mindegyiknek volt egy kicsinyített mása is, az A/4-es papír negyedének megfelelő méretben (4. ábra). Tárolás céljából egy A/4-es méretú, laponként négytasakos mappában kerültek elhelyezésre sorszám, elnevezés és témakör szerint, hasonlóan az óriásábrák elhelyezési rendjéhez. Az előadók az előadás elött ezek alapján válogathatták ki, hogy az adott témához mely ábrák kifüggesztése szükséges. Ez a kicsinyített ábrákat tartalmazó mappa ma is megvan és megtekinthető az intézetben a „Mikrobiológiai Múzeum és Archívum"-ban. Az óriásábrák használata körülbelül az 1960 -as évek végéig tartott. Később előtérbe került az élóbeszéd erősítésére a mikrofonok és hangszórók használata, a fekete-fehér, majd a színes diapozitívok és az írásvetítők alkalmazása is (5. ábra).

\section{Tudományos munkásság}

Az intézet életében az 1950-ben történt események maguk után vonták a kutatási témakörök megváltozását is. Ezekben az években a hazánkban újnak számító leptospirakutatás jelentette az intézet fó tudományos profilját, bakteriológiai és járványtani vonatkozásaival együtt, beleértve a betegség kóroktanának, előfordulásának és fertôzési forrásainak vizsgálatát is. Ezek a kutatások Alföldy professzor vezetésével folytak, aki még az OKI-ban, a Bakteriológiai Osztály akkori vezetőjének, Rauss Károly professzornak a javaslatára már foglalkozott Leptospira törzsek vizsgálatával és szerzett megfelelő tapasztalatokat, de a betegség jelenléte Magyarországon még nem volt kóroktanilag bizonyítva. Intézetvezetôi megbízása idején régi barátja, Veres János dr., a kapuvári kórház fo"orvosa kérte segítségét, mivel az osztályán furcsa meningitisek fordultak elő, és a betegek liquorában sem baktériumot, sem vírust nem sikerült kimutatni. A kórkép leptospirosisra utalt, de a bizonyításhoz a kórokozót ki kellett tenyészteni. Alföldy professzor néhány munkatársával leutazott Kapuvárra és a betegekből hosszas és türelmes tenyésztési munkával, sötét látóteres mikroszkó- 


\section{T TIFUSZ BRCILLUS UTjA}

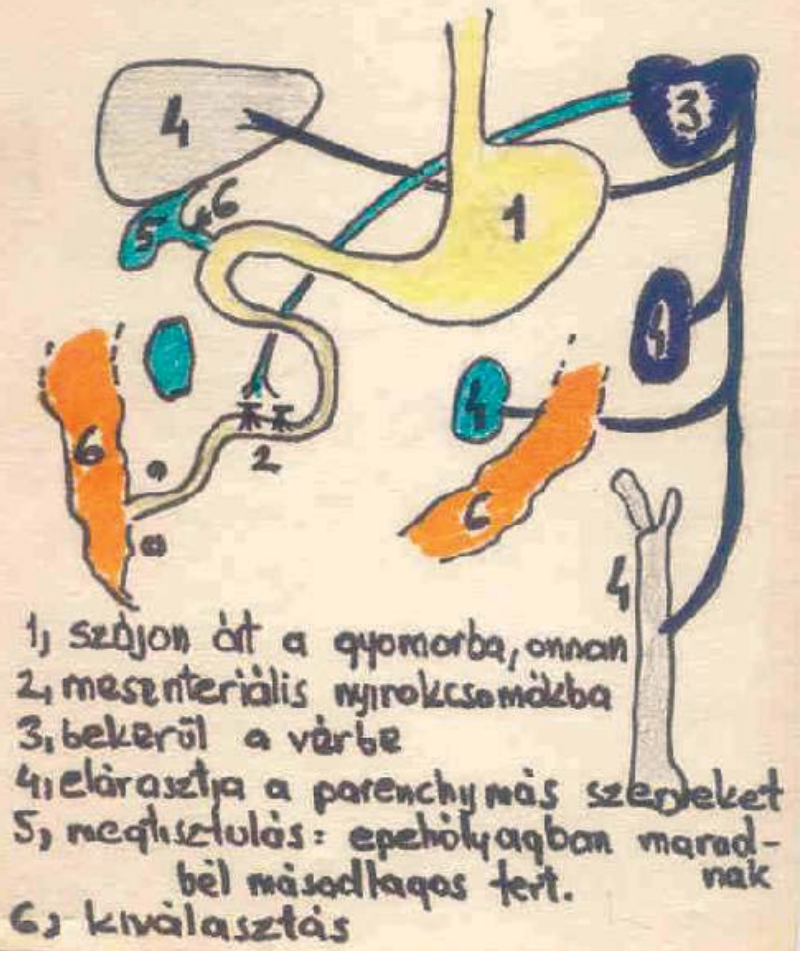

4. ábra

pos vizsgálatok segítségével sikerült a Leptospira baktérium kimutatása, amit Rauss Károly, akkor már mint a pécsi Mikrobiológiai Intézet igazgató professzora is megerösített. Így indult el a Leptospira-kutatás, amely az 1950-es évek körülbelül első kétharmadáig tartott. Meghatározták a hazai leptospirosis előfordulásának törvényszerúségeit. Több meningitis serosa járványban igazolták a Leptospira-etiológiát. Megállapították a Magyarországon előforduló törzsek típusait. Több ezer állat vizsgálatával igazolták, hogy a betegséget elsősorban házi sertések és szarvasmarhák terjesztik, de felderítették a rágcsálók (például mezei egér) útján terjedő leptospirosis forrásait is. Hasznos módszereket dolgoztak ki a szaprofita és a patogén törzsek elkülönítésére és vizsgálták a törzsek antibiotikum-érzékenységét is. Kísérleti fehér patkányból L. budapest néven új törzset is sikerült izolálniuk. Munkásságuk nyomán a leptospirosist bejelentésre kötelezett betegségnek nyilvánították. A Leptospira-probléma állatorvosi jelentősége is nyilvánvalóvá vált.

Alföldy Zoltán professzor a már ismertetett tankönyveken túl számos tudományos továbbképző és gyakorlati diagnosztikai könyvet is írt önállóan vagy társszerzőkkel 1951-1974 között. 1962-ben jelent meg az Akadémiai Kiadónál a Sós professzorral közösen írt „Hőgyes Endre

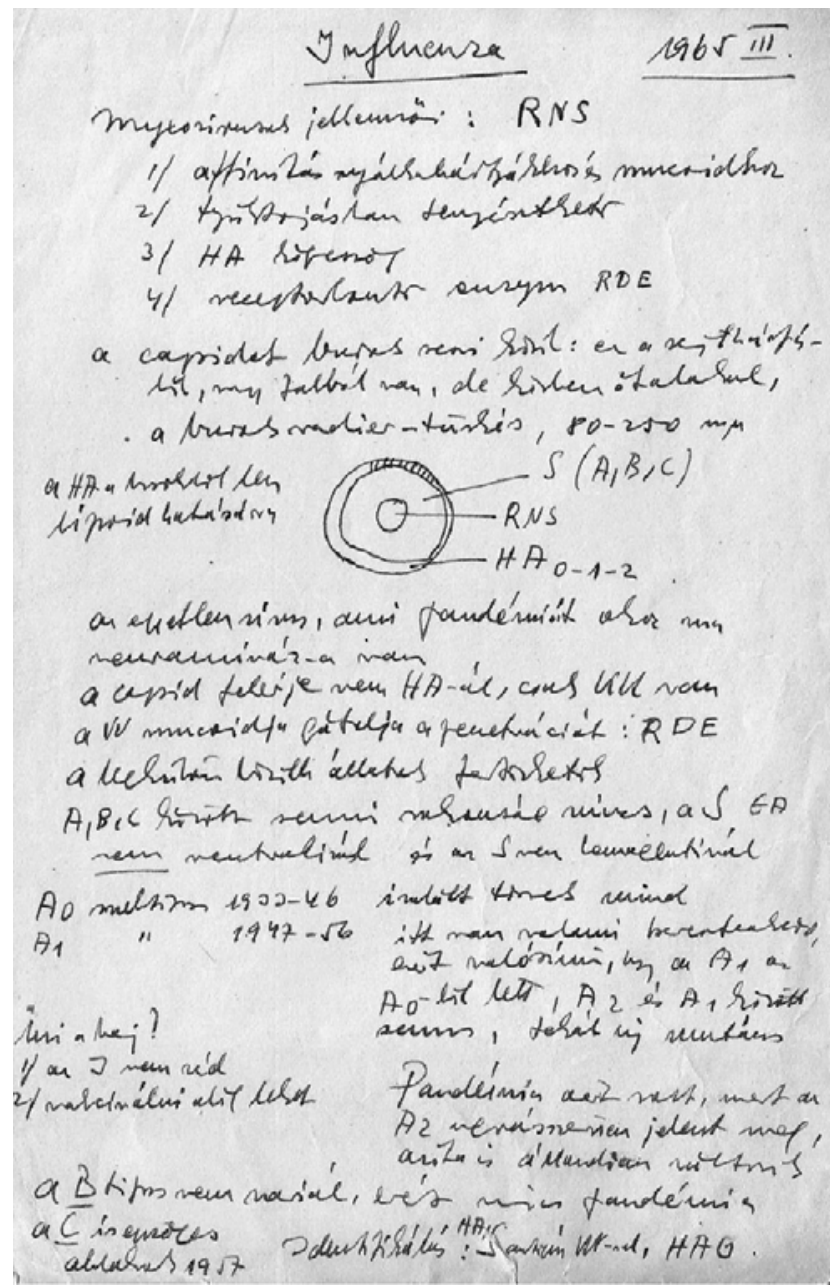

5. ábra Alföldy professzor tantermi előadásának jegyzete az influenza-
vírusról

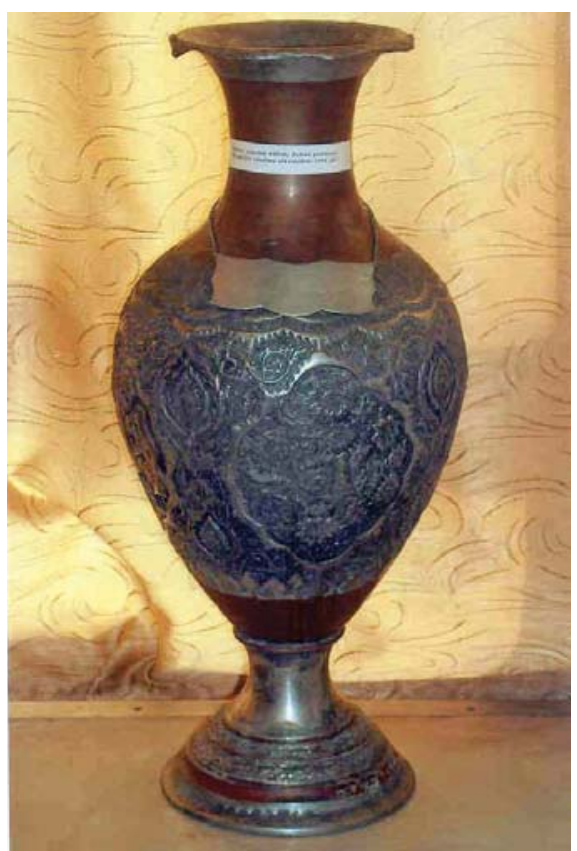

6. ábra

Alföldy professzor nyugállományba vonulása alkalmából az intézet tagjaitól kapott ajándékváza (1974) 
élete és munkássága" című tudománytörténeti monográfiájuk.

Az 1950-es évek legelején bevezették a tudományos fokozatok odaítélését az arra érdemes tudósoknak, és a fiatal kutatók számára meghirdették az aspirantúrát, azaz a fokozat megszerzésére irányuló szervezett lehetőséget. Ezek során Alföldy professzor kandidátusi (PhD) fokozatot nyert és megbízták néhány fiatal aspiráns kutató munkájának irányításával. Az aspiránsok egyike Szeri Ilona, intézetünk tagja volt, aki „Feltételes reflex által előidézett humorális immunválasz lehetőségének kérdése" című kandidátusi értekezését 1961-ben készítette el és védte meg. Az én kandidátusi értekezésem címe „A Salmonella enteritidis var. Danys és a Sarcina flava regenerálódása nem sejtes (szűrhető) formából sejtes formába", amelyet 1955-ben adtam be és 1956-ban védtem meg.

Alföldy professzor támogatásával az intézet tagjai értékes eredményeket értek el a listeriosis és a toxoplasmosis diagnosztikája és járványtana kutatásában. Több, ritkább kórokozó diagnosztikáját fejlesztették bakteriológiai és biokémiai módszerekkel. Felderítették a metronidazol szelektív baktericid hatását. Jelentősek az iatrogén infekciók megelózése szempontjából a müanyagok bakteriológiai megtámadhatóságára vonatkozó vizsgálatok is. Alföldy professzor senkinek sem jelölt ki kutatási munkát, mindenki azzal foglalkozhatott, amivel akart.

A kezdeti bakteriológiai kutatásaim során úgy láttam, hogy a mikrobiológiának a víruskutatás a felmenóben levő ága, és ezért Alföldy professzorral egyetértésben víruskutatással kezdtem foglalkozni. 1956-ban két fiatal munkatársammal megalapítottam az „Adenovíruskutatócsoport”-ot, amelyhez az idők folyamán egyre több fiatal, összesen 32 intézeti kutató csatlakozott és mintegy 50 éven keresztül múködött vezetésem alatt, és több más értékes kutatási terület mellett az adenovíruskutatás az intézetünket jellemző kutatási profillá vált. A csoport munkáját Alföldy professzor mint intézetvezető mindig figyelemmel kísérte és mindenben támogatta, amiben csak lehetett. Például 1964-ben ő szerzett nekem Egészségügyi Világszervezet- (WHO-) ösztöndíjat, ami akkor nagy dolog volt, és amelynek segítségével mintegy fél évig Londonban, a National Research Institute vírusosztályán dolgozhattam H. G. Pereira professzor mellett, az ő adenovírus-kutatásaiban, ami a későbbiekben rendkívül hasznosnak és gyümölcsözőnek bizonyult, nemcsak a magam, hanem az egész csoport kutatómunkája szempontjából. A következőkben a kutatócsoportnak csak azokat a témaköreit és eredményeit ismertetem röviden, amelyeket Alföldy professzor igazgatósága alatti időben, 1974-ig értünk el.

Először izoláltunk hazánkban különböző adenovírusokat kimetszett tonsillák szövettenyészetéból és kimutattuk az adenovírusok adenoid szövetekben való előfordulását. Az 1961-62-ben lezajlott nagy keratoconjunctivitis-járvány kóroktanának felderítésében végzett munka az adenovírus-problémakör tisztázását vitte előre. Több ezer vérminta vizsgálatával kimutattuk az ade- novírusok széles körű hazai elterjedtségét. Új megállapítás volt a vírus citopatogén hatása kétféle jellegének felismerése emberi amnion-sejttenyészeten, továbbá a hemagglutinációs spektrum nemzetközileg is értékelt felderítése. Hasonló értékes eredményt jelentett az immunozmoforézis bevezetése az adenovírusok antigénszerkezetének tanulmányozásában. Kiemelkedőek a virion eltérô antigén-tulajdonságú elemeinek szeparálása és immunbiológiai tulajdonságaik meghatározása. Az adenovírus témakörből írtam a tudomány doktora (az MTA doktora) disszertációt, amelyet 1965-ben védtem meg. 1967-ben Béládi Ilonával és Lengyel Annával egy tudományos monográfiában foglaltuk össze az adenovíruskutatás témakörében addig elért saját tudományos eredményeinket és a témára vonatkozó nemzetközi ismereteket „Az adenovírusok és kórokozó szerepük” címmel, amelyhez Alföldy Zoltán és Ivánovics György professzorok írtak Előszót, amelyet késóbb Akadémiai és Akadémiai Kiadói Nívódíjjal tüntettek ki.

$\mathrm{Az}$ adenovírus-kutatócsoport és az egyénileg dolgozó vagy alkalomszerúen együttmúködő kutatók mellett Földes Pál, majd Szeri Ilona vezetésével múködött egy négytagú immunológiai munkacsoport is, amelynek szintén csak az Alföldy professzor igazgatósága ideje alatt elért eredményeit említem. A csoport az első időkben főleg virológiai módszerekkel végzett, a fertőző immunológia témakörébe tartozó kutatásokkal foglalkozott. A későbbiekben széleskörüen vizsgálták a thymus és a lymphoid rendszer szerepét a specifikus immunválaszban és az általános adaptációban. Elsôként írták le, hogy az újszülöttkori thymectomia, továbbá a graft versus host reakció kivédi egerekben az intracerebralis choriomeningitis vírusfertőzést követő halálos meningitist. Leírták a wasting szindróma korábban nem ismert tüneteit. Felismerték, hogy a lymphoid rendszer károsítása az adaptív immunválasz csökkenésén kívül sorvadással (wasting) és az általános adaptációs készség zavarával jár együtt. Először végeztek hazánkban csíramentesen felnevelt (germfree) állatokon kísérleteket.

\section{Közéleti tevékenység}

Alföldy professzor az oktató- és kutatómunka mellett széles körű tudományos közéleti tevékenységet fejtett ki. Elismerésre méltó munkát végzett mint az Egészségügyi Tudományos Tanács titkára, majd elnökhelyettese, az Egészségügyi Minisztérium Tudományos Kutatási Osztályának vezetője, az Állami és Kossuth-Díj Bizottság albizottságának tagja, a Gyógyszerkönyv Bizottság Biológiai, Mikrobiológiai Bizottságának elnöke, az MTAEü. M. Mikrobiológiai, Járványügyi és Oltóanyag Bizottságának tagja, az Orvosi Hetilap és az Egészségtudomány szerkesztőbizottságának tagja, továbbá mint több hazai és nemzetközi tudományos társaság tagja. Az Országos Szakképesítő Bizottság vizsgáztató tagjaként több évtizeden át ő vizsgáztatta mikrobiológia tárgykörből a szakorvosjelölteket. Az egyetemen évekig volt a 

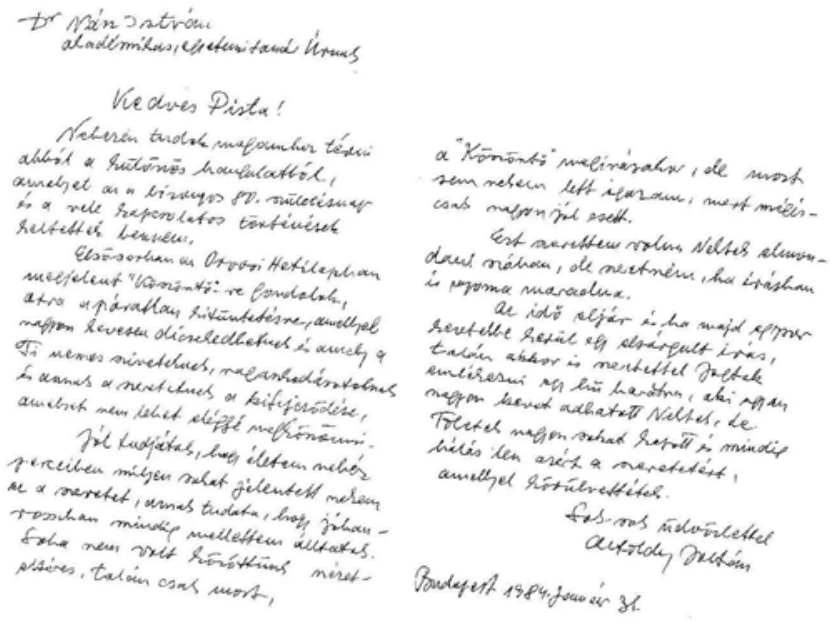

7. ábra

Alföldy professzor válaszlevele 80 . születésnapi köszöntése alkalmából

végzős hallgatókat elosztó bizottság elnöke, ami nehéz és hálátlan feladat volt, mert ez a bizottság határozta meg, hogy az egyes fiatal végzős orvosnak hova - többnyire vidékre - kell mennie dolgozni, általában csak két évre, és csak azután kereshettek új munkahelyet.

Alföldy és Sós professzorok - talán az Egészségügyi Minisztériumban végzett sokrétü tevékenységük révén elévülhetetlen érdemeket szereztek azzal, hogy a Nagyvárad téri Elméleti Tömb (NET) 1971-ben történt alapkőletételét megelőző mintegy 10 éven keresztül tartó érveléssel sikerült meggyőzni az Egészségügyi Minisztérium és a Gazdasági Bizottság illetékeseit arról, hogy a budapesti egyetemnek létszükséglete a NET megépítése.

\section{Kitüntetések}

Kossuth-díj (1962) a leptospirosissal kapcsolatos alapvető kutatásaiért, Kiváló Munkáért érdemérem (1948), Kiváló Orvos (1953), az Oktatásügy Kiváló Dolgozója (1966). Kiemelkedő szakmai munkásságáért Hőgyes Endre-, majd Manninger Rezső-emlékérem, a Munka Érdemrend arany fokozata, Weszprémi-emlékérem, a több kiadást megért mikrobiológiai egyetemi tankönyvért a Medicina Kiadó Nívódíja.

Mindig felelősségteljes oktató, kutató és közéleti elfoglaltsága közben áldozott energiát a tanítványok és munkatársak nevelésére. Az intézeti munkatársait nagy családjának tartotta. Mi, intézeti tagok is szerettük és nagyra becsültük ôt. Mivel a nőnap és a Zoltán-nap azonos napon van, ezt a két eseményt mindig együtt, közös intézeti összejövetelen ünnepeltük, ahol gyakran mesélt életéről. Nyugdíjba vonulásakor (1974) egy iparművészeti vázával ajándékoztuk meg (6. ábra). 80. születésnapján az Orvosi Hetilapban megjelent írással köszöntöttük és az Acta Microbiologia Hungarica 1983. évi 3-4. összevont számát díszes kötésben neki dedikáltuk. Mindezeket külön, szerény és barátságos levelekben köszönte meg (7. ábra). Szinte élete végéig szaktanácsadóként bejárt az intézetbe. Hosszú és nehéz betegségében szelleme töretlenségét, széles körü érdeklődését és ítélőképességét mindvégig megörizte és gyümölcsöztette. 1992. október 16-án hunyt el.

Alföldy professzor életútja, szakmájának szeretete, mély humánuma, önzetlen szerénysége példaként áll tanítványai, munkatársai és intézetünk mindenkori tagjai elött.

Alföldy professzorra szeretettel és mély tisztelettel emlékezünk!

\section{Felhasznált irodalom}

[1] Antoni, F., Székely, S. (ed.): The history of the Clinics and Institutes of the Semmmelweis Medical University (1945-1975). [A Semmelweis Orvostudományi Egyetem Klinikáinak és Intézeteinek története (1945-1975).] Egyetemi Kiadvány, Budapest, 1976. [Hungarian]

[2] Sinkovics, J.: Serum disaster 1950. [Szérumszerencsétlenség, 1950.] Orvostörténeti Közlemények, 1999, 44, 77-106. [Hungarian]

[3] Kövesné Terstyánsky, E.: Zoltán Alföldi. (In: Medical Scientists.) [Alföldy Zoltán. In: Gyógyító tudósok.] Minerva Kiadó, Budapest, 1982. [Hungarian]

[4] Nász, I., Ádám, É., Szabó, D.: Short history of teaching and research of microbiology in the Institute of Medical Microbiology, Semmelweis University (1948-2015) In: Vincze, J. (ed.): Remember our physicians, 22. [A mikrobiológia oktatásának és kutatásának rövid története a Semmelweis Egyetem Orvosi Mikrobiológiai Intézetében (1948-2015). In: Vincze, J. (szerk.): Emlékezünk orvosainkra 22.] NDP Kiadó, Budapest, 2015. [Hungarian)

[5] Szeri I., Nász I.: Professor Zoltán Alföldy is 80 years old. [Alföldy Zoltán professzor 80 éves.] Orv. Hetil., 1984, 125(4), 187-188. [Hungarian]

(Nász István dr., Budapest, Nagyvárad tér 4., 1089 e-mail:nasz.istvan@med.semmelweis-univ.hu) 